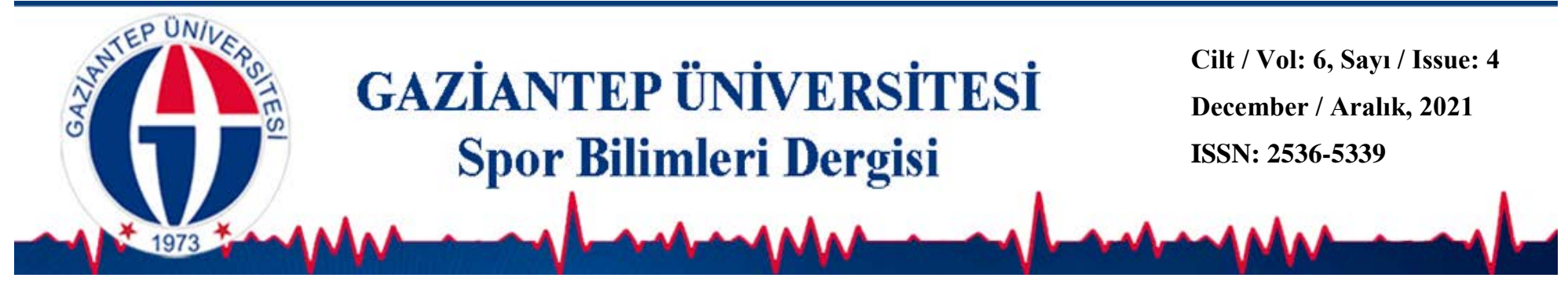

\title{
The Effect of Different Training Models on Some Selected Physical Parameters in 13-14 Years Old Children Playing Football
}

\author{
Mustafa BINGÖL ${ }^{1}$ Mücahit SARIKAYA ${ }^{1+}$ iD \\ ${ }^{1}$ Van Yüzüncüyıl Üniversitesi, Beden Eğitimi ve Spor Yüksekokulu, VAN
}

\begin{abstract}
Orijinal Makale / Original Article
\end{abstract}
Geliş Tarihi / Received: 19.11.2021～Kabul Tarihi / Accepted: 06.12.2021Ｙayın Tarihi / Published: 24.12.2021

\begin{abstract}
The aim of this study is to examine some selected physical parameters of male football players in the 13-14 age group of different 8-week training programs. The football players participating in the study consisted of 4 different groups: plyometric $n=12$, core $n=12$, resistance band $n=12$, control $n=12$. Wet weight, vertical jump, standing long jump, hand grip strength, back leg strength and leg strength tests were applied to all 4 groups before and after the study. Normality homogeneity test was applied to the obtained data and it was determined that the data showed a normal distribution and Paired-sample T test was applied for paired group comparisons from parametric tests and One-Way Anova test was applied for intergroup comparisons. Obtained findings were tested statistically at $p<0.05$ significance level. When the pre-test and post-tests were compared as a result of the exercises, a significant change was found in the vertical jump, standing long jump, hand grip strength, back leg strength in all groups compared to the pre-test.
\end{abstract}

Keywords: Football, strenght, exercise

\section{Futbol Oynayan 13-14 Yaş Çocuklarında Farklı Antrenman Modellerinin Seçilmiş Bazı Fiziksel Parametrelere Etkisi}

Öz

Bu çalışmanın amacı 8 haftalık farklı antrenman programlarının 13-14 yaş gurubunda ki futbol oynayan erkek sporcuların seçilmiş bazı fiziksel parametrelerinin incelenmesidir. Çalışmaya katılan futbolcular pliometrik $n=12$, core $n=12$, direnç lastiği $n=12$, kontrol $n=12$ olmak üzere 4 farklı gruptan oluşmuştur. 4 gruba da çalışma öncesi ve sonrası olmak üzere yaş boy ağırlık, dikey sıçrama, durarak uzun atlama, el kavrama kuvveti, sırt bacak kuvveti ve bacak kuvveti testleri uygulanmıştır. Elde edilen verilere normallik homejenlik testi uygulanmış olup verilerin normal bir dağılım gösterdiği tespit edilmiş ve parametrik testlerden ikili grup karşılaştırmaları için Paired-sample T testi, gruplar arası karşılaştırmaları için One-Way Anova testi uygulanmıştır. Elde edilen bulgular istatistiksel olarak $\mathrm{p}<0,05$ anlamlılık düzeyinde test edilmiştir. Yapılan egzersizler sonucunda ön test ve son testler karşılaştırıldığında tüm gruplarda dikey sıçrama, durarak uzun atlama, el kavrama kuvveti, sırt bacak kuvvetlerinde ön testine göre anlamlı bir değişim tespit edilmiştir.

Anahtar Kelimeler: Futbol, kuvvet, egzersiz 


\section{Introduction}

Weight control and improvement can be improved with core training, the risk of injury can be reduced by strengthening many large and small muscles, and the balance associated with increases in movements or transitions between movements. (Herrington and Davies, 2005). Recently, core training has become the concept that receives the most support and attention in the fitness industry. The origin of core training is based on anatomical adaptation and rehabilitation, and it is used for the treatment of injuries in the lower back with clinical findings. In addition to this, core training is now implemented with commercial matches. Core exercises are also recommended for healthy individuals to increase the functional capacity of individuals and for the development of their athletic abilities (Willardson, 2014; Özdal et al. 2019; Pancar, 2020).

Plyometric exercises are one of the most important and effective training applications for strength. Another aspect of plyometric studies is to increase the sportive efficiency and especially the explosive power of the athlete, as a method that allows to increase the work shown per unit time. In these studies, training equipment related to body weight or additional weight is used. (Dündar, 2015; Pancar, Biçer, Özdal, 2020; Pancar, 2020).

With the changes to be made in exercise programming, changes that may be beneficial for the body can also be achieved (Taşdoğan et al. 2020). These changes can be counted as an increase in overall strength and conditioning level. In resistance band exercises, using higher resistance with less repetitions helps increase muscle size and strength, and using lower resistance with more repetitions helps maintain existing muscle strength. (Page and Ellenbecker, 2011; Özer et al. 2017). Sudden changes in body parts during growth bring some difficulties in displaying motoric features. This link Girard and Millet (2009). In a study they conducted, they stated that the physical characteristics of tennis players aged 13-19 were important and effective in the performance exhibited specific to tennis, and some asymmetrical changes occurred that caused fluctuations in sportive performance. In the same study, it was emphasized that this imbalance would be eliminated and the possibility of injury would be minimized with the arrangements to be made in the training programs by the trainers. 


\section{Material And Method}

\section{The Universe of the Research}

The universe of the research; It consisted of 48 male football players who played football for at least 5 years in the 13-14 age group in secondary schools affiliated to the National Education in Van in 2018-2019 ( $\mathrm{n}=48)$.

Group 1 (n:12): The group continuing their routine soccer training

Group 2 (n:12): Core+ soccer training

Group 3 (n:12): plyometric + soccer training

Group 4 (n:12): resistance rubber + soccer training

Height and Body Weight Measurement

The height of the children participating in the study was measured with the height scale technique with a sensitivity of $0.01 \mathrm{~cm}$. Lengths; The measurement was made after taking a position with the head straight and facing forward, bare feet with a normal stance, the heels of the feet fully united, holding the breath until the height is taken, in a way that the upper part of the head touches the determined point. The values obtained from the measurement were recorded in $\mathrm{cm}$. While measuring body weight, the same $0.1 \mathrm{~kg}$ precision digital scale was used. The athletes whose height will be measured are ready for the test by removing the clothes and shoes that will weigh on them and standing on the scales with bare feet, and after this stage, the test value of each subject is recorded in kg. (Mackenzie, 2005; Pancar ve ark. 2018).

\section{Vertical jump}

The test protocol was introduced to the athletes and the measurements were made with a Verti Metric device. This instrument was used to analyze and interpret the vertical jump height of the athlete and the power of the lower body (lower extremity) against a certain resistance. For the measurement, the subjects wore the accelerometer on their legs and jumped, 3 measurements were taken and the highest value was recorded ( Altunbaş, 2019).

\section{Back Strength Measurement Test}

Measurements were made using Takei brand back and leg dynamometer. After the warm-up, the subjects placed their feet on the dynamometer bench with their knees tense, and with their arms stretched, with their back and body slightly bent forward, they pulled the dynamometer bar that they grasped with their hands vertically, using their legs to exert maximum force. This movement was repeated three times, and the 
best values for each athlete were written on the forms prepared in advance and recorded (Altunbaş, 2019).

\section{Leg Strength Measurement Test}

Takei brand back and leg (back and lift) dynamometer was supplied and measurements were made. With a certain warm-up (5-6 minutes), the athletes, after placing their feet on the dynamometer bench with their knees bent, with the arms tense, with the back and body slightly bent forward, by pulling the dynamometer bar vertically up with their hands to the maximum. They pulled the bar up by using their legs to apply force. This movement was repeated three times, and the best values for each athlete were written on the forms prepared in advance and recorded (Altunbaş, 2019).

\section{Hand Grip Strength Measurement}

Measurements were made with Takei brand hand dynamometer (Hand Grip). 5-6 min. Measurements were made while the athletes were standing, right after the warm-up phase. These measurements were repeated three times for both the right and left hands, and the highest values were recorded (Saygın et al. 2005).

\section{Standing Long Jump Test}

The subject, who will participate in the test, took the test starting position with his knees bent at a 45-degree angle outside the area indicated by lines at the beginning of the sandbox, and with his feet shoulder-width apart, again with his arms left behind. In the other stage, the athlete performed the forward jump as soon as he felt ready. At the end of the jump, the distance between the point where the athlete was before the jump and the place where he left the closest trace to this point after the jump was measured. Measurements were taken twice and the best distance was recorded as $\mathrm{cm}$ (Mackenzie, 2005; Pancar et al. 2018).

\section{Analysis of Data}

SPSS 17.0 package program was used in the analysis of the data. Normality homogeneity test was applied to the obtained data and it was determined that the data showed a normal distribution and Paired-sample $T$ test was applied for paired group comparisons from parametric tests and One-Way Anova test was applied for intergroup comparisons. Obtained findings were tested statistically at $p<0.05$ significance level. 


\section{Findings}

Table 1. Demographic information of female athletes participating in the research.

\begin{tabular}{|c|c|c|c|c|c|}
\hline & & Groups & $\mathbf{N}$ & Average & Std. Dv. \\
\hline \multirow{12}{*}{ Male } & \multirow{4}{*}{ Age } & $K A G$ & 10 & 12.98 & 0.88 \\
\hline & & $P A G$ & 10 & 11.7 & 0.85 \\
\hline & & DLAG & 10 & 12.5 & 0.83 \\
\hline & & $K G$ & 10 & 13.23 & 0.86 \\
\hline & \multirow{4}{*}{ Height (cm) } & $K A G$ & 10 & 152.3 & 9.67 \\
\hline & & PAG & 10 & 151.2 & 8.89 \\
\hline & & DLAG & 10 & 152.1 & 9.65 \\
\hline & & $K G$ & 10 & 153.4 & 6.67 \\
\hline & \multirow{4}{*}{$\begin{array}{c}\text { Body } \\
\text { weight }(\mathrm{kg})\end{array}$} & $K A G$ & 10 & 39.4 & 5.67 \\
\hline & & PAG & 10 & 38.3 & 11.67 \\
\hline & & DLAG & 10 & 40.4 & 7.90 \\
\hline & & $K G$ & 10 & 42.5 & 4.67 \\
\hline
\end{tabular}

Table 2. Comparison of the vertical jump pre-test and post-tests of the athletes participating in the study.

\begin{tabular}{clllll}
\hline \multicolumn{1}{c}{ Variables } & \multicolumn{1}{c}{ Group } & Avrg. & Std. D. & F & P \\
\hline \multirow{4}{*}{ Vertical jump pre Test } & Core & 37,49 & 3,80 & & \multirow{2}{*}{0,12} \\
\cline { 2 - 4 } 2,01 & Plyometric & 33,61 & 2,90 \\
\cline { 2 - 4 } Vertical jump post Test & Resistance Rubber & 35,38 & 5,42 \\
\cline { 2 - 4 } & Control & 33,62 & 2,98 \\
& Core & 41,62 & 4,18 & \multirow{2}{*}{$0,01^{*}$} \\
\cline { 2 - 4 } & Plyometric & 40,15 & 3,43 \\
\cline { 2 - 4 } & Resistance Rubber & 38,62 & 5,38 & & \\
\cline { 2 - 4 } & Control & 35,92 & 4,11 & & \\
\hline
\end{tabular}

The comparison of the vertical jump in-group pre-test and post-test of the students participating in the study is shown in Table 2. Vertical jump pre-test core training (37.49 \pm 3.80$)$, pre-test plyometric $(33.61 \pm 2.90)$, pre-test resistance tire (35.38 \pm 5.42$)$, control pre-test $(33.35 \pm 2.98)$ data was determined, and no statistically significant result was detected ( $p>0.05)$. Vertical jump post-test core training of the participants $(41.62 \pm 4.18)$, post-test plyometric $(40.15 \pm 3.43)$, post-test resistance elastic (38.62 \pm 6.38$)$, control post-test $(35.92 \pm 4.11)$ data were found, and no statistically significant result was found ( $p>0.05$ ).

Table 3. Comparison of the right hand pre-test and post-tests of hand claw strength within the group of the students participating in the study.

\begin{tabular}{|c|c|c|c|c|c|}
\hline Variables & Group & Avg. & Std.d & $f$ & $p$ \\
\hline \multirow{5}{*}{$\begin{array}{c}\text { Hand Grip Strength Right } \\
\text { Hand Pre-Test }\end{array}$} & Core & 20,4 & 3,40 & \multirow{4}{*}{6,80} & \multirow{4}{*}{$2,38^{*}$} \\
\hline & Plyometric & 18,90 & 4,21 & & \\
\hline & Resistance Rubber & 19,38 & 4,23 & & \\
\hline & Control & 18,44 & 3,18 & & \\
\hline & Core & 29,62 & 3,51 & & \\
\hline
\end{tabular}




\begin{tabular}{cccc}
\hline \multirow{3}{*}{$\begin{array}{c}\text { Hand Grip Strength Right } \\
\text { Hand Post-Test }\end{array}$} & Plyometric & 29,95 & 3,44 \\
\cline { 2 - 3 } & Resistance Rubber & 31,23 & 5,18 \\
\cline { 2 - 4 } & Control & 23,02 & 3,29 \\
\hline
\end{tabular}

The comparison of the hand claw strength of the students participating in the study in the right hand in-group pre-test post-test is shown in Table 3. Participants' hand grip strength, right hand pre-test core training (117.5 \pm 3.66$)$, pre-test plyometric (13.4 \pm 4.57$)$, pre-test resistance elastic $(17.64 \pm 4,91)$, control pre-test $(21.85 \pm 3.38)$ data, and a statistically significant result was determined $(p<0.05)$. Hand grip strength of the participants, right hand post-test core training $(28.57 \pm 3.68)$, pre-test plyometric (35.95 \pm 45.54$)$, post-test resistance rubber $(31.51 \pm 5,18)$, control post-test (28.95 \pm 3.38$)$ data, and no statistically significant result was found ( $p>0.05)$.

Table 4. Comparison of intra-group leg strength pre-test and post-test of the athletes participating in the study.

\begin{tabular}{|c|c|c|c|c|c|}
\hline Variables & Group & Avg & Std. D. & $f$ & $p$ \\
\hline \multirow{4}{*}{ Leg Strength Pre-Test } & Core & 48,90 & 12,92 & \multirow{4}{*}{7,53} & \multirow{4}{*}{0,116} \\
\hline & Plyometric & 49,80 & 9,46 & & \\
\hline & Resistance Rubber & 44,45 & 11,14 & & \\
\hline & Control & 45,13 & 10,53 & & \\
\hline \multirow{4}{*}{ Leg Strength Post-Test } & Core & 60,38 & 8,36 & \multirow{4}{*}{5,70} & \multirow{4}{*}{$0,00 *$} \\
\hline & Plyometric & 67,75 & 10,59 & & \\
\hline & Resistance Rubber & 54,92 & 8,46 & & \\
\hline & Control & 52,46 & 9,45 & & \\
\hline
\end{tabular}

The comparison of the leg strength of the students participating in the study within the group pre-test and post-test is shown in Table 4. The participants' leg

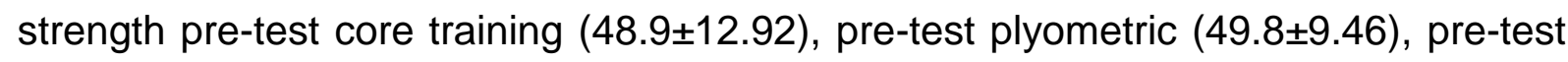
resistance elastic (44.45 \pm 11.14$)$, control pre-test $(45.13 \pm 12.58)$ data were determined and no statistically significant result was detected $(p<0.05)$. Participants' leg strength post-test core training $(70.38 \pm 12.36)$, post-test plyometric $(67.75 \pm 10.59)$, post-test resistance elastic $(51.92 \pm 11.46)$, control It was determined that there were post-test (72.46 \pm 14.45$)$ data and a statistically significant result was determined $(p<0.05)$. 
Table 5. Comparison of intra-group back strength pre-test and post-test of the athletes participating in the study.

\begin{tabular}{|c|c|c|c|c|c|}
\hline Variables & Group & Avg & Std d. & $f$ & $p$ \\
\hline \multirow{4}{*}{ Back Strength Pre-Test } & Core & 52,38 & 7,35 & \multirow{4}{*}{8,20} & \multirow{4}{*}{2,38} \\
\hline & Plyometric & 49,43 & 7,99 & & \\
\hline & Resistance Rubber & 50,90 & 6,65 & & \\
\hline & Control & 49,29 & 8,63 & & \\
\hline \multirow{4}{*}{ Back Strength Post-Test } & Core & 70,58 & 6,69 & \multirow{4}{*}{15,58} & \multirow{4}{*}{$0,00^{*}$} \\
\hline & Plyometric & 57,69 & 7,13 & & \\
\hline & Resistance Rubber & 59,23 & 6,88 & & \\
\hline & Control & 53,11 & 7,39 & & \\
\hline
\end{tabular}

The comparison of the back strength of the students participating in the study within the group pre-test and post-test is shown in Table 5. Back strength pre-test core

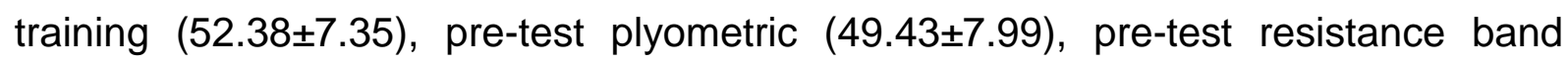

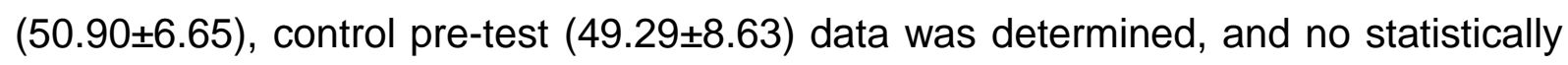
significant result was detected $(p<0.05)$. Participants' back strength post-test core training (70.58 \pm 6.69$)$, post-test plyometric $(57.69 \pm 7.13)$, post-test resistance band (59.23 \pm 6.88$)$, control post-test $(53.11 \pm 7.39)$ data was determined and a statistically significant result was determined $(p<0.05)$.

Table 6. Comparison of the long jump pre-test and post-tests of the athletes participating in the study by standing within the group.

\begin{tabular}{|c|c|c|c|c|c|}
\hline Variables & Group & Avg & Std. D & $f$ & $\mathrm{p}$ \\
\hline \multirow{4}{*}{$\begin{array}{c}\text { Standing Long Jump Pre- } \\
\text { test }\end{array}$} & Core & 129,20 & 7,74 & \multirow{4}{*}{5,33} & \multirow{4}{*}{7,68} \\
\hline & Plyometric & 124,80 & 8,61 & & \\
\hline & Resistance Rubber & 125,20 & 7,11 & & \\
\hline & Control & 131,90 & 13,14 & & \\
\hline \multirow{4}{*}{$\begin{array}{c}\text { Standing Long Jump } \\
\text { Post-test }\end{array}$} & Core & 148,58 & 7,33 & \multirow{4}{*}{5,65} & \multirow{4}{*}{$0,00^{*}$} \\
\hline & Plyometric & 151,39 & 8,30 & & \\
\hline & Resistance Rubber & 143,30 & 6,69 & & \\
\hline & Control & 141,80 & 12,38 & & \\
\hline
\end{tabular}

The comparison of the standing long jump in-group pre-test post-test of the students participating in the study is shown in Table 6. The participants' standing long

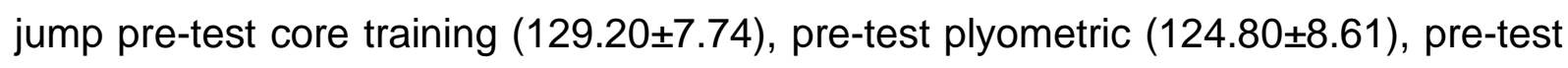
resistance elastic $(125.2 \pm 7.11)$, control pre-test $(131.9 \pm 13.14)$ data were determined and a statistically significant result was determined $(p<0.05)$. Standing long jump posttest core training of the participants (148.58 \pm 7.33$)$, pre-test plyometric $(151.39 \pm 8.30)$, 
post-test resistance elastic $(143.30 \pm 6.69)$, control post-test $(141.8 \pm 12.38)$ data were found and a statistically significant result was found $(p<0.05)$.

\section{Discussion And Conclusion}

In this study, the effects of core, plyometric and resistance band training applied for eight weeks on selected strength parameters were investigated. Age, height, weight, vertical jump, standing long jump, hand grip strength, back and leg tests were performed on the volunteers participating in the study, and the results were compared with similar studies and discussed.

In our research, in the vertical jump values; Significance was determined in the pre-test and post-test $p<0.05$ value of all groups. The group with the highest level of significance was the group in which plyometric training was performed. It can be said that this significance is due to the explosiveness of the jumps in a very short period of time in plyometric training and, accordingly, the development of both explosive power and explosive feature (Chu, 1984; Kubo et al, 2007; Pancar and et al, 2018; Erdoğan and Karadağ, 2017; Selçuk et al, 2018). In the study, statistical significance was observed in the pre-test and post-test values of the standing long jump control group and experimental groups $(\mathrm{p}<0.05)$. The fact that the standing long jump values of the experimental group were higher than the control group can be explained by the effect of the exercises aimed at improving both the sharing power and explosive properties of these exercises. Studies investigating the effects of core, plyometric and resistance exercises on standing long jump and jump performance reported that plyometric exercises performed at various and different intensities significantly improved jump performance.

On the other hand, in a study conducted by Gür in 2001, it was reported that plyometric training lasting 3 months could cause a positive change and development on the leg strength, anaerobic power and body composition of young football players. From the findings of Altunbaş in a study he conducted in 2019, it was determined that the plyometric training program applied regularly for 8 weeks contributed significantly to the leg strength development of young tennis players. In our study, as it can be seen in Table 4 as a result of plyometric exercises, when the data we obtained regarding leg strength are examined, a statistically significant improvement was observed in the leg strength at $p<0.05$ when comparing the intra-group leg strength pre-test and posttests. In their study in 2016, AICl and Afyon reported a significant increase in the abilities of flexible female swimmers, such as left hand grip, leg and back strength, and 
an 8-week core training program. These findings support our results obtained from the CAG group in our study.

According to the data obtained in another study, it is understood that 10-week core exercise has a positive effect on dominant and non-dominant paw strength and an increase in hand grip strength. In a study conducted on sedentary individuals, it was stated that 8-week core and plyometric exercises improved right and left hand claw strength (Afyon \& Boyaci, 2013). Some motoric features of the core training program in our study; strength, standing long jump, vertical jump, hand-grip strength, back-leg strength were investigated. In our study, no significant difference was found between the groups in the vertical jump right hand strength post-test findings, but a statistically significant change at the $p<0.05$ level was observed in all other parameters related to the experimental group. It is a normal result of the core training program to increase the strength and endurance of the core muscles. The fact that more effective results can be obtained from core training is limited to 8 weeks of training. In addition, we think that it is normal that the expected results cannot be obtained in some parameters, since the age range coincides with the pre-adolescence period and large changes can be seen in the physical dimensions of children in this period.

\section{References}

Afyon, Y. A., \& Boyaci, A. (2013). Investıgatıon Of The Effects By Composıtely Edited Core-Plyometrıc Exercıses in Sedentary Man on Some Physıcal and Motorıc Parameters. Internatıonal Journal Of Academıc Research, 5(3).

Altundağ M. (2019). Farklı Antrenman Metodlarının Tenisçilerde Forehand Ve Backhand Vuruş Hızına Ve Seçilmiş Bazı Motorik Özelliklere Etkilerinin İncelenmesi. Yüksek Lisans Tezi. Yüzüncü Yıl Üniversitesi Eğitim Bilimleri Enstitüsü, Beden Eğitimi Spor Anabilim Dalı.

Atici, M., Afyon, Y., A., (2016). The effects of core training on swimming in sedentary women. The anthropologist, (ISSN:0972-0073), 23(3), 542-549.

Dündar, U., ( 2015). Antrenman Teorisi 9. Baskı. Ankara: Nobel Akademik Yayıncılık.

Girard, O., Millet, G.P. (2009). Physical Determinants Of Tennis Performance In Competitive Teen Age Players. The Journal Of Strength And ConditioningResearch. September, 23 (6) 1867-1872.

Gür, F., Ersöz, G. (2017). Kor Antrenmanın 8-14 Yaş Grubu Tenis Sporcularının Kor Kuvveti, Statik Ve Dinamik Denge Özellikleri Üzerindeki Etkisinin Değerlendirilmesi. Spormetre, 15 (3), 129-138. 
Herrington, L. \& Davies, R. (2005). The Influence Of Pilates Training On The Ability To Contract The Transverses Abdominis Muscle in a symptom aticindividuals. Journal of Body work and Movement Therapies. 9 (1), 52-57.

Karadağ, M., \& Erdoğan, R. (2017). Masa tenisi ve kort tenisi oynayan öğrencilerin bazı fiziksel parametrelerinin karşılaştırılması. Türkiye Klinikleri Journal of Sports Sciences, 9(3), 118-23.

Mackenzie, B. (2005). 101 Performance Evaluation Test. London: Electric Word Plc. Erişim.

Özdal M, Biçer M, Pancar Z. (2019). Effect on an eight-week core strength training on one-leg dynamic balance in male well-trained athletes. Biology of Exercise. 15(1), 125-135.

Özer Y, Bozdal Ö, Pancar Z. (2017). Acute Effect of Circuit Aerobıc and Traditional Aerobic Training on Hamstring Flexibility in Sedentary Women. European Journal of Physical Education and Sport Science. 3(12):268-275.

Page, P., Ellenbecker, T. (2011). Strength Band Training. Second Edition. USA, Human Kinetics, p. 3-16.

Pancar Z, Biçer M, Özdal M. (2020). The effect of 8-week plyometric training on anaerobic power, balance and sprint performance of 12-14 aged female handball players. Medicina Dello Sport. 73(1):1-10.

Pancar, Z. (2020b). Effect of Core Exercises on Thyroid Metabolism in Men. Gaziantep Üniversitesi Spor Bilimleri Dergisi. 5(4): 590-597.

Pancar, Z. (2020c). Effect of short-term plyometric exercises on element metabolism in adolescents. Gaziantep Üniversitesi Spor Bilimleri Dergisi. 2020; 5(4):566572.

Pancar, Z., Biçer, M., \& Özdal, M. (2018). 12-14 Yaş Grubu Bayan Hentbolculara Uygulanan 8 Haftalik Pliometrik Antrenmanlarin Seçilmiş Bazi Kuvvet Parametrelerine Etkisi. Spor Ve Performans Araştırmaları Dergisi, 9(1), 18-24.

Saygin Ö, Polat, Y\&Karacabey, K. (2005). Çocuklarda Hareket Eğitiminin Fiziksel Uygunluk Özelliklerine Etkisi. Fırat Üniversitesi Sağlık Bilimleri Dergisi, 19(3), 205-212.

Selcuk M, Cinar V, Sarikaya M, Oner S \& Karaca S. (2018). The effect of 8-week pliometric exercises on some physiological parameters of male basketballers aged 10-14 years. European Journal of Physical Education and Sport Science. 
Bingöl M, Sarıkaya M. (2021). The Effect of Different Training Models on Some Selected Physical Parameters in 13-14 Years Old Chıldren Playing Football. Gaziantep Üniversitesi Spor Bilimleri Dergisi, 6(4), 424-434.

Taşdoğan A.M. Vural M, Özdal M, Pancar Z. (2020). Effect of royal jelly supplementation on aerobic power output and anaerobic power output. Progress in Nutrition. Vol. 22.

Wildorson, J.M. (2014). Developing the core, nsca-national strength \&conditioning association. İstanbul: Karakış Basım Matbaacılık. 